\title{
THE PLIGHT OF FIRST-YEAR TEACHERS IN PUBLIC PRIMARY SCHOOLS
}

\author{
Xiaotian Han \\ School of Primary Education, Shanghai Normal University Tianhua College (China)
}

\begin{abstract}
First-year teachers are teachers who are new to teaching. The number of public school teachers is increasing in many countries and areas. Meanwhile, data also showed that some newly qualified teachers anticipated leaving or already left after the first year teaching. The purpose of the study aims to present a review and synthesize literature regarding the challenges of first-year teachers in public primary schools. Peer-reviewed articles $(\mathrm{N}=30)$ are collected from Google Scholar via systematically searching key words "first-year teachers" with one or more of the following terms: challenge, difficulty, attrition, leaving, and public primary schools. The results show first-year teachers meet general challenges listed as below: (a) building a professional teacher identity, (b) applying teaching theories in real class practice, and (c) handling the same heavy teaching loads and responsibilities as experienced teachers. In addition, first-year teachers in Shanghai public primary schools also meet the following challenges: (d) not having enough pre-service teaching programs, (e) facing high competition and a workload, and (f) building positive and stable relationships with parents/administrators. Considering by new qualified teachers' internal motivation and the external challenge they meet, first-year teachers are overwhelmed in dealing with these imbalances.
\end{abstract}

Keywords: First-year teachers, challenges, public primary schools.

\section{Introduction}

First-year teachers are teachers who are new to teaching. The number of public school teachers is increasing in many countries and areas. In California, the number of public K-12 teachers has been increasing every year since 1985 (National Center for Education Statistics, 2015). In Shanghai, the number of public primary teachers has been increasing sharply since 2015. Compared to the number of teachers in 2010 (44,278 teachers), there were 51,481 and 52,321 teachers serving in Shanghai public primary schools in 2015 and 2016 (Shanghai Statistics Yearbook, 2017). The data indicate that more teachers are joining the profession.

Meanwhile, data also showed that some newly qualified teachers anticipate leaving or already left after the first year teaching. In the United States, researchers widely accepted a study result that forty to fifty percent of novice teachers (teaching experience from one to three years) quit within the first five years of teaching by analyzing federal data in 2003, which is a much higher rate than in any other occupation and it becomes a primary factor for the shortage of teachers (DeAngelis \& Presley, 2010; Ingersoll, 2004; Ingersoll, 2012). However, this first-year teacher retention rate approximation is critiqued by the U.S. Department of Education's National Center for Educational Statistics because "the data included private school teachers and excluded the $3 \%$ of teachers who left and returned to teach within the five-year period" (Fensterwald, 2015). In the new U.S study, researchers used 2007-2008 federal data from only public school teachers and calculated that ten percent of U.S. first-year teachers in the public schools left the profession and did not return (Darling-Hammond, 2000). Although the data is changed, the first-year teacher attrition rate is concerned. In the United Kingdom, $12 \%$ of newly qualified teachers are planning to leave their positions after their first year teaching and $43 \%$ of teachers thought that teaching was not their life-long job (Bai, 2018). In China, a nation-wide survey discovered that first-year teachers account for a major proportion of the $65 \%$ anticipated teacher attrition rate. In Shanghai, how to retain new-qualified teachers and support their professional development is in the Shanghai Government Plan (the period of 2016-2020).

Research indicated that high teacher attrition will lead to negative consequences. Two of the negative consequences are financial crisis and low student achievement. The U.S. government spent $\$ 1$ billion on recruiting new teachers and $\$ 2.2$ billion on replacing teachers in 2014 (Alliance for Excellent Education, 2005; Duncan, 2009). To renew teaching credentials and support new teachers in their first two 
years, California's budget provided $\$ 66$ million to support over 12,000 beginning teachers in 1998 and \$128 million to support 30,118 first-year teachers in 2007-2008 (Report on New Teacher Induction, 2015). Similarly, the Shanghai government has funded more teacher support in the current decade. According to the data from the Shanghai Teacher Training Center, the funds for teacher professional development is constantly increasing from 2,742.36 million yuan in 2015 to 3,851 million yuan in 2017, and to 7,772 million yuan in 2018 (Shanghai Teacher Training Center, 2015; 2016; 2017). If the attrition rate of first-year teachers is going to rise, the amount of funding will be wasted.

Generally, first-year teachers have high motivation for teaching and learning. As Brookhart and Freeman (1992) stated, "altruistic, service-oriented goals and other intrinsic motivations are the source of the primary reasons entering teacher candidates report why they chose teaching as a career" (p. 46). Also, researchers reported that beginning teachers have "a desire to work with children and adolescents," which stimulates their learning/teaching attitudes, expectations, and engagement in the first year (Löfström \& Poom-Valickis; Watt \& Richardson, 2008). However, first-year teachers do face various extrinsic challenges.

The purpose of the study aims to present a review and synthesize literature regarding the challenges of first-year teachers in public primary schools. Peer-reviewed articles $(\mathrm{N}=30)$ are collected from Google Scholar via systematically searching key words "first-year teachers" with one or more of the following terms: challenge, difficulty, attrition, leaving, and public primary schools.

\section{The challenges of first-year teachers in public schools}

First, they are expected to build a professional teacher identity in a very short time. In other words, they need to transform from a student teacher to a teacher of students quickly. However, building and exploring teacher identity should be an ongoing process, developed over years of teaching experience and reflection, instead of a stable identity (Erikson, 1986). The procedure of this transformation includes a series of observations, imitations, explorations, reflections, and practices. In the process, teachers need to consistently explore and reflect on questions such as, "Who am I at this moment", "Who do I want to become", and "How and from where do teacher educators develop their understandings of what is means to do their work?" (Conway, 2001). To answer these questions and develop a professional teacher identity in their first-year teaching is challenging and overwhelming (Beijaard, 1995; Zhang, Ding, \& Xu, 2016).

The second challenge is that first-year teachers are expected to skillfully apply teaching theories in real class practice; however, they are overwhelmed, most of time by the tasks of delivering instructions and managing class (Banville, 2015; McAnulty \& Cuenca, 2014; Tsui, 2004). Moreover, Flores (2006) studied a group of beginning teachers in Europe and realized that they were struggling to achieve the expected performance -- "learning while doing", at school, so many beginning teachers switched from a student-centered classroom to traditional lecture (p. 2021).

The third challenge is that first-year teachers are expected to handle the same heavy teaching loads and responsibilities as experienced teachers (Banville, 2015). Renard (2003) argued that "schools often overwhelm new teachers by expecting them to juggle all the responsibilities and duties that veteran teachers do. Instead, we need to give new teachers to grow" (p. 62). Researchers suggested school and district administrators improve new teacher retention by adjusting their workloads in teacher induction programs such as avoiding to assign them to the most challenging grade level or students, avoiding to assign extra duties (i.e.: intervention, committee members, student council advisor), and assigning first-year teachers the same planning period with their mentors (Farrell, 2003; Clark, 2012)). However, the reality is not ideal. According to Alliance for Excellent Education (2005), a Washington, DC-based national policy and advocacy organization, reported that, $60 \%$ of teachers transferred schools or left teaching because of too heavy a workload. In both England and Finland, new teachers experienced extensive national-level curriculum and assessment, which challenges them and becomes a main reason of turnover (Webb et al., 2004). Expecting new teachers to perform all responsibilities as experienced teachers is unrealistic (Allen, 2000). When first-year teachers meet these workloads as seasoned professionals, new teachers often fall into a feeling of "demoralized and dispirited, anxious about their efficacy and their capability to cope" (Scott, 1995, p. 96). These experience and perceptions persuade them to leave the teaching profession (DeAngelis \& Presley, 2010; Ingersoll, 2004; Ingersoll, 2012).

\section{The challenges of first-year teachers in Shanghai public schools}

In addition to the above general first-year teachers' challenges, first-year teachers in Shanghai public primary schools have additional challenges. First, new-qualified teachers may not have enough training because teacher preparation programs are not mandatory in Shanghai public primary schools. Being a primary school teacher is only required to have a bachelor degree (four-year college/university 
degree) or a higher degree and a Shanghai teaching credential. Teachers in Shanghai public primary schools are all specialists rather than all-subject teachers in other countries. Based on their college majors, teachers can be categorized into three groups: general educations, core course majors (i.e., Chinese, Math, and English), and subsidiary course majors (i.e., science, arts, and physical education). For teachers who major in education, they experienced approximate 20 weeks a teacher preparation program/intern program in the four-year college setting so they are automatically issued the credential (Ding, 2011; Xia, 2018). However, for teachers whose majors were other than education (core course majors and subsidiary majors) and were willing to train into teaching, they did not experience any teaching practice but concentrated on all subject-based courses in their universities, they must take a teaching credential test (Chen \& An, 2016; Xia, 2018). The credential test is a law and subject knowledge based written and oral test. It does not require class practice hours. Therefore, the latter group of first-year teachers may lack practice in classroom teaching when they are hired.

Second, first-year teachers are expected to build positive and stable relationships with colleagues, administrators, parents, and students (Ren, 2014). However, they always feel powerless and isolated in the first years (Zhao, 2003). Cao and Zhou (2007) pointed out that dealing with student-teacher relationships is the greatest challenge first-year teachers meet. Knowing students well and having positive relationships with students are relative to course design, planning and organization, motivating students' interests, and delivering differentiated instructions. However, first-year teachers are not confident in building teacher-student relationships.

Third, Shanghai public school teachers are facing high competition and a workload. They are expected to show high student academic achievements via standardized exams and a series of government interventions than teachers in some other countries (Gao, 2008; Ministry of Education, 2010). To improve students' academic scores, they must bear heavy workloads -- their average working time is 9.16 hours per day without extra-time payment $(\mathrm{Wu}, 2018)$. Considering by new qualified teachers' internal motivation and the external challenges they meet, first-year teachers are overwhelmed in dealing with these imbalances.

\section{Summary}

Literature review shows that first-year teachers meet general challenges listed as below: (a) building a professional teacher identity, (b) applying teaching theories in real class practice, and (c) handling the same heavy teaching loads and responsibilities as experienced teachers. In addition, first-year teachers in Shanghai public primary schools also meet the following challenges: (d) not having enough pre-service teaching programs, (e) facing high competition and a workload, and (f) building positive and stable relationships with parents/administrators. Considering by new qualified teachers' internal motivation and the external challenge they meet, first-year teachers are overwhelmed in dealing with these imbalances.

\section{References}

Allen, M. (2000). Teacher preparation and induction. Retrieved from https:/files.eric.ed.gov/ fulltext/ED473451.pdf

Alliance for Excellent Education. (2008). What keeps good teachers in the classroom? Understanding and reducing teacher turnover. Washington, DC: Alliance for Excellent Education.

Bai, M. (2018). Ying guo jiao shi gong hui diao cha xian shi gong zuo liang da dao zhi jiao shi li zhi. Retrieved from http://www.jyb.cn/zgjyb/201801/t20180126_945084.html

Beijaard, D. (1995). Teachers' prior experiences and actual perceptions of professional identity. Teachers and Teaching: Theory and Practice, 1(2), 281-294.

Cao. L., \& Zhou. Y. (2007). Xiao xue jiao shi ru zhi chu qi chang yu wen ti ji jie jue dui ce. He Tian Shi Fan Zhuan Ke Xue Xiao Xue Bao, 27(3), 68-69.

Chen, X. \& An, G. (2016). On the new induction education system for primary and secondary teachers in Shanghai. Teacher Education Research, 28(2), 45-50.

Clark, S. K. (2012). The plight of the novice teacher. The Clearing House: A Journal of Educational Strategies, Issues and Ideas, 85(5), 197-200. doi:10.1080/00098655.2012.689783

Conway, P. (2001). Anticipatory reflection while learning to teach: From a temporally truncated to a temporally distributed model of reflection in teacher education. Teaching and Teacher Education, 17, 89-106.

Darling-Hammond, L. (2000). Teacher quality and student achievement: A review of state policy evidence. Education Policy Analysis Archives, 8(1), 1-44. 
Deangelis, K. J., \& Presley, J. B. (2010). Toward a more nuanced understanding of new teacher attrition. Education and Urban Society, 43(5), 598-626.

Ding, G. (2011). Report of Chinese teacher professional development survey and policy analysis. Shanghai: East China Normal University Press.

Duncan, A. (2011). The Obama administration's plan for teacher education. Retrieved from https://www.ed.gov/sites/default/files/our-future-our- teachers.pdf

Erikson, E. H. (1986). Identity, youth and crisis. New York: W.W. Norton \& Company.

Farrell, T. (2003). Learning to teach English language during the first year: personal influences and challenges. Teaching and Teacher Education, 19(1), 95-111.

Fensterwald, J. (2015). Half of new teachers quit profession in 5 years? No true, new study says. Retrieved from https://edsource.org/2015/half-of-new-teachers-quit-profession-in-5-years-not-truenew-study-says/83054

Gao, X. (2008). Teachers' professional vulnerability and cultural tradition: A Chinese paradox. Teaching and Teacher Education, 24, 154-165.

Ingersoll, R. M. (2004). Do teacher induction and mentoring matter? NASSP Bulletin, 88(638), 28-40.

McAnulty, J., \& Cuenca, A. (2014). Embracing institutional authority: The emerging identity of a novice teacher educator. Studying Teacher Education, 10(1), 36-52.

New Teacher Center. (2016). New teacher development for every inning. Retrieved from https://newteachercenter.org/wp-content/uploads/NewTeacherDevelopmentEveryInning.pdf

Odell, S. J., \& Ferraro, D. P. (1992). Teacher mentoring and teacher retention. Journal of Teacher Education, 43(3), 200-204. doi:10.1177/0022487192043003006

Ren, S. (2014). The implementation research of Shanghai "standardized training programs for new teachers" in base school (Master thesis). Retrieved from http://kns.cnki.net/KCMS/detail/detail.aspx?dbcode=CMFD\&dbname=CMFD201701\&filename= 1016126006.nh\&v=MTgwMzZyV00xRnJDVVJMT2ZadWRzRnl2aFdydktWRjI2R0xLNkdOSE1 xWkViUEISOGVYMUx1eFITN0RoMVQzcVQ

Shanghai Educational Municipal Commission: Shanghai Teacher Professional Development Program Leading Group. (Eds.). (2017). Effective strategies for new teacher standardized training. Shanghai: East China Normal University Press.

Shanghai Municipal Education Commission (2013). Education statistics 2013. Shanghai: Shanghai Education.

Shanghai Municipal Government (2016). The 13th five-year plan for Shanghai education reform and development.

Tsui, A. B. (2004). Understanding expertise in teaching. Understanding Expertise in Teaching, 245-282. doi:10.1017/cbo9781139524698.011

Wu, G. (2018). Shanghai primary and secondary school teachers occupational status and policy suggestions. Retrieved from http://news.sina.com.cn/c/2014-03-10/080529668179.shtml

Xia, Z. (2018). Review on the normalized induction manual for Shanghai primary and secondary school trainee teacher. Journal of Schooling Studies, 15(2), 55-65.

Zhang, M., Ding, X., \& Xu, J. (2016). Developing Shanghai's teachers. National Center on Education and Economy, Report.

Zhang, P. (2017). Gaokao: How one exam can set the course of a student's life in China. Retrieved from https://www.scmp.com/news/china/society/article/2097512/gaokao-how-one-exam-can-set-coursestudents-life-china

Zhao, C. (2003). The study on teachers' growth (Doctoral dissertation). Retrieved from CNKI. (Accession: G451) 